\title{
Thornwaldt Cyst: Case Report
}

\author{
Kiran L. Kulsange, Smita Nagle, Mohan Jagade, Pallavi Gupta, Madhavi Pandhare, Kartik Parelkar, \\ Arpita Singhal, Devkumar Rangaraja, Reshma Hanwate, Nataraj Rajanala Venkata, Bandu Nagrale, \\ Ankur Walli, Karthik Rao, Sudam Gaware
}

Grant Government Medical College and Sir JJ Groups of Hospital, Mumbai, India

Email: kirankul555@gmail.com

How to cite this paper: Kulsange, K.L., Nagle, S., Jagade, M., Gupta, P., Pandhare, M., Parelkar, K., Singhal, A., Rangaraja, D., Hanwate, R., Venkata, N.R., Nagrale, B., Walli, A., Rao, K. and Gaware, S. (2016) Thornwaldt Cyst: Case Report. International Journal of Otolaryngology and Head \& Neck Surgery, 5, 203-207.

http://dx.doi.org/10.4236/ijohns.2016.55032

Received: April 26, 2016

Accepted: September 27, 2016

Published: September 30, 2016

Copyright $\odot 2016$ by authors and Scientific Research Publishing Inc. This work is licensed under the Creative Commons Attribution International License (CC BY 4.0).

http://creativecommons.org/licenses/by/4.0/

\begin{abstract}
Thornwaldt cyst is benign, mucosal congenital cyst which is located in upper nasopharynx. It developed in nasopharyngeal bursa if opening of bursa is occluded due to infection or inflammation. It is rare congenital cyst present in nasopharyngeal bursa. Its incidence is $3 \%$ in adults [1]. The usual age of presentation is $2^{\text {nd }}$ and $3^{\text {rd }}$ decade [1]. It is usually asymptomatic and incidental finding on MRI but it can present as nasal obstruction, post nasal drip, halitosis, occipital headache, foreign body sensation in throat [1] [2]. Here we are presenting a case report of 23 years old male presented with foreign body sensation in throat since 5 months. On oral and nasal endoscopic examination cystic mass in nasopharynx seen, bulging in oropharynx. MRI shows cystic mass arising from left side of nasopharynx popping up in oropharynx. Cyst then excised with diode laser with both endonasal and transoral approach with zero degree rigid endoscope. Histopathology confirmed the cyst as thornwaldt cyst.
\end{abstract}

\section{Keywords}

Thornwaldt Cyst, Diode Laser, Endosnasal and Transoral Approach

\section{Introduction}

Thornwaldt cyst is rare congenital cyst present in nasopharyngeal bursa formed by communication between notochord and nasopharyngeal endoderm [1] [3]. Most cases are diagnosed in $2^{\text {nd }}$ and $3^{\text {rd }}$ decade of life. Its incidence has been reported to be $3 \%-7 \%$ in the general population, $0.2 \%$ in magnetic resonance imaging (MRI), and $3 \%-4 \%$ in postmortem studies [4]. It is seen in both sexes equally. Patient is usually asymptomatic but may present with nasal obstruction, foreign body sensation, nasal obstruction, halitosis, post nasal discharge. The diagnosis of this mass is usually incidental in MRI or autopsy. The differential diagnosis should include a meningocele or meningoencephalocele. 
Benign and asymptomatic cyst does not require any surgical intervention. If symptomatic then surgery with marsupialisation is method of choice.

\section{Case Report}

In this case report, a 23 years old man presented with foreign body sensation in throat since 6 months and had sensation of something coming in oropharynx while swallowing. There was no pain associated with it. In oral examination, a smooth-surfaced, cystic mass found bulging in oropharynx. Nasal endoscopic examination reveals that cystic massarisisng from posterior wall of nasopharynx and coming in oropharynx, of around $2 \times 2 \mathrm{~cm}$, smooth surfaced, with broad base freely moving with act of swallowing (Figure 1). On MRI it reveals that mass is cystic containing fluid arising from posterior wall of nasopharynx most probably thornwaldt cyst. There was no destruction of surrounding bone. As cystic mass was arising from nasopharynx and popping up in oropharynx we planned for surgical intervention and approach is both endonasal and transoral with zerodegree endoscope. Excision is done with the use of diode laser. We freed the margins of wall from its base towards nasopharynx (Figure 2). Fluid coming is aspirated for cytology and its wall vaporised from all sides with the help of diode laser. Histopahology confirmed the cyst as thornwaldt cyst. There was minimal bleeding intraopeartively, with less trauma to surrounding structures. In Immediate post operative period, there was no bleeding and minimal crustations present (Figure 3(a) and Figure 3(b)). On further follow up period of 6 months no crusting, synechae or recurrence seen.

\section{Discussion}

Thornwaldt cyst developed as a recess, called Thornwaldt's bursa, formed by the remnants of the notochord tissue with pharyngeal respiratory epithelium along the midline

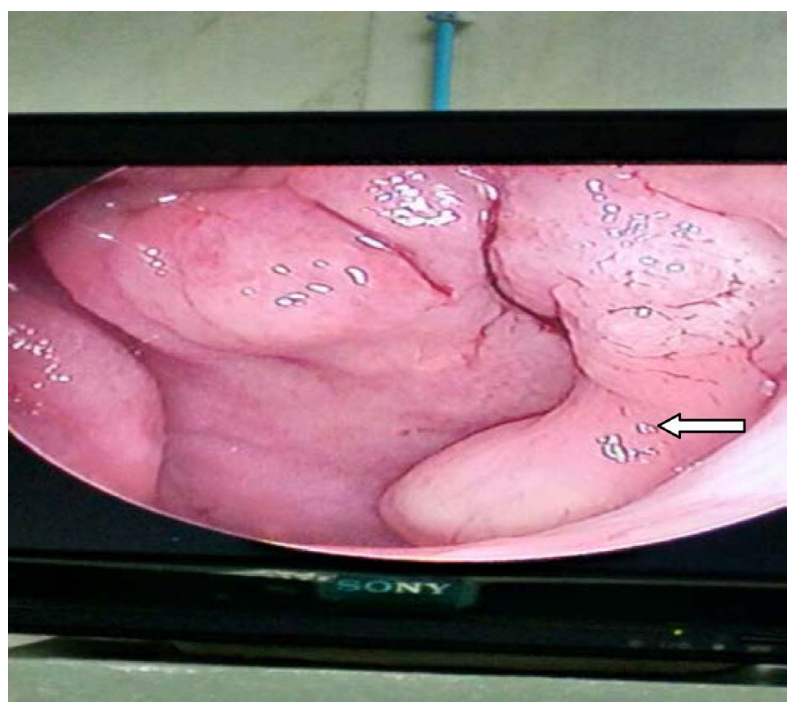

Figure 1. Nasal endoscopic picture arrow showing cystic mass arising from posterior wall of nasopharynx and popping up in oropharynx. 


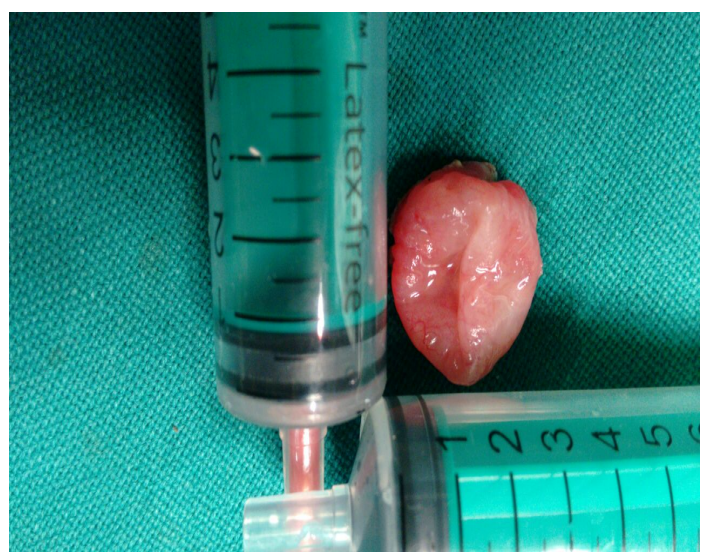

Figure 2. Picture showing excised cyst with the help of diode laser through both approaches endonasal and transoral with measurements $3 \times 3 \mathrm{~cm}$.

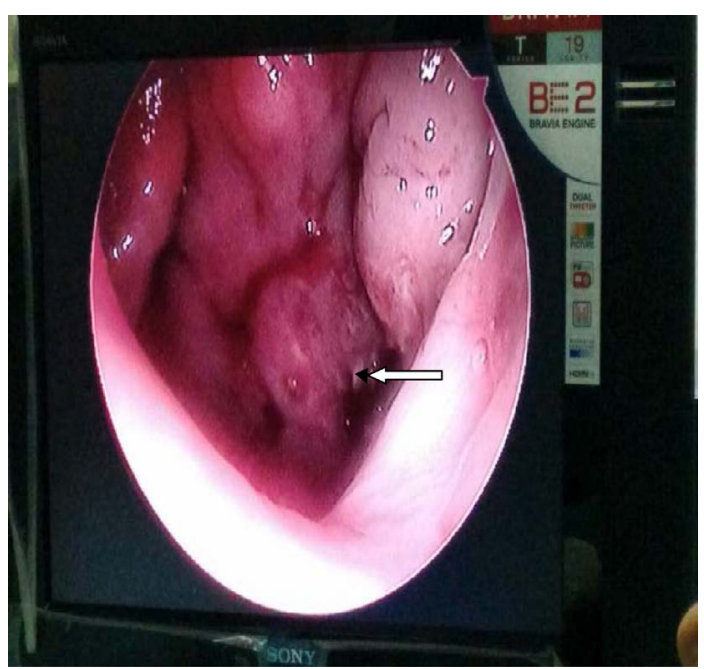

(a)

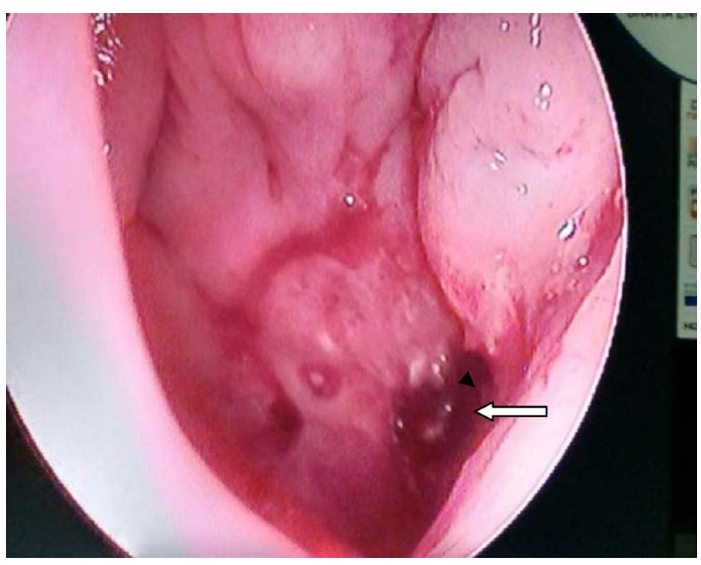

(b)

Figure 3. (a) Picture showing in immediate post operative periodon nasal endoscopy arrow showing minimal crusts at the site of lesion; (b) nasal endoscopic picture showing the site of lesion with arrow on immediate follow up period. 
wall of the nasopharynx [5]. It is rare congenital cyst. It is mostly asymptomatic. It is usually incidental finding on MRI or autopsy.

When nasopharyngeal mass is encountered, Thornwaldt cyst, branchial cleft cyst, Rathke's pouch cyst, adenoid retention cyst, meningocele or meningoencephalocele, choanal polyp, sphenoid sinus mucocele, angiofibroma, nasopharyngeal carcinoma, and papillary thyroid cancer metastases should be considered in the differential diagnosis [2] [6] [7]. Nasopharyngeal mass has been differentiated from meningocele and meningoencephalocele owing to intact skull base bones and from mucocele due to normal sphenoid sinus. Other differential diagnoses can be performed only after a pathological examination. In this nasal endoscopy and radiologic investigation play important role in diagnosis. Nasal endoscopy should be considered important routine investigation on routine basis.

Thornwaldt cyst can easily be detected by nasopharyngoscopy and imaging methods. CT or MRI techniques should be used for evaluating asymptomatic and submucosal lesions, most of which are smaller than $10 \mathrm{~mm}$ [8].

Surgical intervention can be performed under local or general anesthesia, depending on the size of the cyst and the presence of the symptoms. If the Thornwaldt cyst is small in size and asymptomatic, surgical treatment is not needed. For the treatment of a symptomatic and large cyst leaning on the torus tubarius, the cyst is marsupialized with surgical intervention of transoral or endonasal endoscopic approaches [9] [10]. Microdebrider, laser, and computer-assisted endoscopic surgeries can also be used as advanced endoscopic surgery techniques. Marsupialization of the cyst by using a transoral approach with an angled microdebrider and a $70^{\circ}$ endoscope can be performed with less bleeding and less trauma on the surrounding tissues [9]. However, the difficulty in the histopathological evaluation due to the loss of palpation feeling and of tissue integrity and the need for practical experience are the disadvantages of the microdebrider technique [11].

We chose laser for excision of cyst. The use of laser in rhinology provides less bleeding [4] [12], less thermal necrosis of surrounding structures, less chances of adhesion post operatively, easy to handle, flexible, good visualisation of structures with the help of endoscope, reduced post operative pain [13]. On the other hand, the cost of the system per patient, the need for a special technician and equipment limits the use of laser [9] and also anatomical variation in nose like septal deviation, turbinate hypertrophy limits the use of nasal endoscopic approach which can be corrected.

In the case presented, with both the approaches endonasal and transoral with zero degree rigid endoscope, cyst is excised by diodelaser. The method was efficient, better visualisation of cyst while excising along with less trauma to surrounding structures. Post operative result is also good.

\section{Conclusion}

The use of diode laser gives better post op result and also both the approaches endonasal and transoral with the help of 0 degree endoscope give better visualisation of cyst 
and surrounding structures making it easy and efficient alternative procedure for excision.

\section{References}

[1] Weissman, J.L. (1992) Thornwaldt Cysts. American Journal of Otolaryngology, 13, 381-385. http://dx.doi.org/10.1016/0196-0709(92)90080-D

[2] Miyahara, H. and Matsunaga, T. (1994) Tornwaldt's Disease. Acta Oto-Laryngologica, 114, 36-39. http://dx.doi.org/10.3109/00016489409124336

[3] Brown, S. (2008) Textbook of Otolaryngology. Hodder Arnold, Great Britain, 2122.

[4] Shapshay, S.M., Rebeiz, E.E., Bohigian, R.K., Hybels, R.L., Aretz, H.T. and Pankratov, M.M. (1991) Holmium: Yttrium Aluminium Garnet Laser-Assisted Endoscopic Sinus Surgery: Laboratory Experience. Laryngoscope, 101, 142-149. http://dx.doi.org/10.1288/00005537-199102000-00008

[5] Huber, G.C. (1912) On the Relation of the Chorda Dorsalis to the Anlage of the Pharyngeal Bursa or Median Pharyngeal Recess. The Anatomical Record, 6, 373-404. http://dx.doi.org/10.1002/ar.1090061002

[6] Uslu, S.S., İleri, F., Sezer, C., Asal, K., Köybaşığlu, A. and İnal, E. (1999) Koanal polipler: Orijin, mikroskopi ve yaklaşım. K.B.B. ve Baş Boyun Cerrahisi Dergisi, 7, 79-84.

[7] Pineda-Daboin, K., Neto, A., Ochoa-Perez, V. and Luna, M.A. (2006) Nasopharyngeal Adenocarcinomas: A Clinicopathologic Study of 44 Cases Including Immunohistochemical Features of 18 Papillary Phenotypes. Annals of Diagnostic Pathology, 10, 215-221. http://dx.doi.org/10.1016/j.anndiagpath.2005.11.002

[8] Chong, V.F. and Fan, Y.F. (2000) Radiology of the Nasopharynx: Pictoral Essay. Journal of Medical Imaging and Radiation Oncology, 44, 5-13. http://dx.doi.org/10.1046/j.1440-1673.2000.00765.x

[9] Eloy, P., Watelet, J.B., Hatert, A.S. and Bertrand, B. (2006) Thornwaldt's Cyst and Surgery with Powered Instrumentation. B-ENT, 2, 135-139.

[10] Özünlü, A., Önder, T., Aktaş, D. and Özkaptan, Y. (1996) Nazofarengeal kistler. Kulak Burun Boğaz Bülteni, 3, 48-51.

[11] Ünlü, H.H. (2004) Endoskopik sinus cerrahisinde ileri teknikler. In: Koç, C., Ed., Kulak Burun Boğaz Hastalıklarıve Baş Boyun Cerrahisi. Volume 1. Güneş Kitabevi Ltd., Baskı. 669-683.

[12] Metson, R. (1996) Holmium: YAG Laser Endoscopic Sinus Surgery: A Randomized, Controlled Study. Laryngoscope, 106, 1-18. http://dx.doi.org/10.1097/00005537-199601001-00001

[13] Cintra, P.P.V.C. and Anselmo-Lima, W.T. (2003) Comparação das técnicas de turbinectomia com laser de CO2 e laser a diodo. Revista Brasileira de Otorrinolaringologia, 69, 612-620. http://dx.doi.org/10.1590/S0034-72992003000500005 
Submit or recommend next manuscript to SCIRP and we will provide best service for you:

Accepting pre-submission inquiries through Email, Facebook, LinkedIn, Twitter, etc. A wide selection of journals (inclusive of 9 subjects, more than 200 journals)

Providing 24-hour high-quality service

User-friendly online submission system

Fair and swift peer-review system

Efficient typesetting and proofreading procedure

Display of the result of downloads and visits, as well as the number of cited articles

Maximum dissemination of your research work

Submit your manuscript at: http://papersubmission.scirp.org/

Or contact ijohns@scirp.org 